\title{
ANALISIS KETELITIAN HASIL PENGAMATAN GNSS METODE RADIAL BERDASARKAN LAMA PENGAMATAN UNTUK EFISIENSI PENGUKURAN GROUND CONTROL POINT
}

\author{
Khomsin ${ }^{1}$, Ira Mutiara Anjasmara², Rizky Romadhon ${ }^{3}$ \\ 1,2,3 Departemen Teknik Geomatika, FTSLK-ITS, Kampus ITS Sukolilo, Surabaya, 60111, Indonesia \\ e-mail: ${ }^{1}$ khomsin@geodesy.its.ac.id, ${ }^{2}$ ira@geodesy.its.ac.id, ${ }^{3}$ rizromadhon@gmail.com
}

\begin{abstract}
Abstrak
Saat ini GNSS memiliki peran yang sangat penting di bidang survei pemetaan, terutama dalam menentukan koordinat GCP untuk keperluan foto udara, citra satelit resolusi tinggi dan LiDAR. Masing-masing proses rektifikasi ini membutuhkan akurasi koordinat yang berbeda antara $5 \mathrm{~cm}$ hingga $30 \mathrm{~cm}$. Sering kali pelaksanaan pengukuran GCP tidak sesuai dengan perencanaan karena faktor non teknis. Oleh karena itu sangatlah penting untuk menentukan waktu minimum yang efektf untuk pengukuran GCP di lapangan. Penelitian ini bertujuan untuk menjawab permasalahan yang ada dengan melakukan pengolahan data GNSS dengan interval 15 menit dengan metode radial. Dengan demikian dapat diketahui berapa lama waktu yang dibutuhkan dan metode apa yang digunakan untuk mendapatkan akurasi minimum pengukuran GCP foto udara, CSRT dan LiDAR. Secara umum hasil penelitian menunjukan bahwa semakin lama pengamatan GNSS akan menghasilkan koordinat yang lebih akurat, dari ketelitian $0,923 \mathrm{~m}$ pada pengamatan $15^{\prime}$ hingga $0,011 \mathrm{~m}$ pada pengamatan $120^{\prime}$. GCP dengan baseline $0-10 \mathrm{~km}$ menggunakan metode radial selama 15' dapat memperoleh akurasi kurang dari $5 \mathrm{~cm}$. Hasil pengamatan tersebut dapat digunakan untuk rektifikasi foto udara resolusi $10 \mathrm{~cm}$, CSRT dan LiDAR. Panjang baseline 10-20 km membutuhkan waktu 90' untuk dapat digunakan untuk GCP foto udara resolusi $10 \mathrm{~cm}$, sedangkan CSRT dan LiDAR membutuhkan waktu pengamatan GCP 75'.
\end{abstract}

Kata kunci: GNSS, GCP, Metode, Lama Pengamatan, Ketelitian

\begin{abstract}
Nowadays, GNSS has a very important role in the field of surveying and mapping, especially in determining the coordinates of ground control points for the purposes of rectifying aerial photogrametry, satellite imagery and airborne LiDAR. Each of these rectification processes requires a different coordinate accuracy from $5 \mathrm{~cm}$ to $30 \mathrm{~cm}$. Often, the implementation of GCP measurements in the field is not in accordance with the planning due to several factors. Therefore it is necessary to find an effective time for GNSS measuring in the field. This research aims to answer the existing problem that is by doing data processing GNSS with interval 15' with radial method. How long will it take and what method is used to obtain the desired accuracy for GCP measurement for rectification of photos, satellite imagery and airborne LiDAR. In general, the results showed that the longer the GNSS observation will give the more accurate coordinates from $0.923 \mathrm{~m}\left(15^{\prime}\right)$ to $0.011 \mathrm{~m}\left(120^{\prime}\right)$. GCP observations with baseline $0-10 \mathrm{~km}$ using radial method for 15' can obtain accuracy less than $5 \mathrm{~cm}$. It means that they can be used for rectification for aerial photogrametry, satellite imagery and airborne LiDAR. For 10-20 km baseline, GNSS observation with 90' has accuracy less than $5 \mathrm{~cm}$ and this can be used rectification for aerial photogrametry. Finally, high resolution satellite imagery and airborne Lidar can be rectified by $75^{\prime}$ of GNSS observation.
\end{abstract}

Keywords: GNSS, GCP, Method, Observation, Accuracy 


\section{PENDAHULUAN}

Global Navigation Satellite System (GNSS) merupakan suatu istilah yang digunakan untuk mencakup seluruh sistem satelit navigasi global yang sudah beroperasi ataupun sedang dalam perencanaan. Penentuan posisi dapat dilakukan berdasarkan 4 (empat) dimensi, yaitu berdasarkan garis bujur, garis lintang, ketinggian dan waktu (Bakara 2011). Salah satu satelit GNSS yang paling dikenal saat ini adalah Global Positioning System (GPS). Semua sistem dalam hal ini GPS, GLONASS, Galileo dan juga Compass memiliki cara kerja yang hampir sama sehingga deskripsi cara kerja GPS berikut untuk mengetahui prinsip kerja GNSS (Prasetyaningsih 2012). Dibandingkan dengan sistem dan metode penentuan posisi lainnya, GPS mempunyai banyak kelebihan dan menawarkan lebih banyak keuntungan, baik dalam segi operasionalnya maupun kualitas posisi yang diberikan (Abidin 2000). Terdapat banyak sekali kegiatan yang memerlukan implementasi dari pengamatan GNSS. Salah satunya adalah untuk pengukuran Ground Control Point (GCP). GCP merupakan titik bantu untuk proses pemberian koordinat pada citra atau bisa disebut proses georeferencing yang bertujuan untuk koreksi geometrik. Proses georeferencing merupakan proses pemberian sistem koordinat pada suatu objek gambar dengan cara menempatkan suatu titik kontrol terhadap suatu persimpangan antar garis lintang dan garis bujur pada gambar tersebut. Titik GCP yang digunakan untuk koreksi geometrik harus memiliki koordinat yang akurat sesuai dengan kebutuhan (Pribadi 2016).

Pengamatan GCP dengan menggunakan GNSS ini berfungsi untuk koreksi geometrik pada citra foto udara, citra satelit resolusi tinggi (CSRT) maupun LiDAR. Pengukuran GCP dapat dilakukan dengan menggunakan metode radial maupun jaring, dengan perbandingan jumlah baseline, sesi dan waktu pengukuran antara moda jaring dan radial dalam penentuan posisi menggunakan GPS dengan metode statik adalah moda radial lebih membutuhkan jumlah baseline, sesi dan waktu pengukuran yang lebih sedikit (56\%) apabila dibandingkan dengan moda jaring. Masingmasing citra yang dihasilkan memerlukan titik kontrol dengan ketelitian tertentu. Foto udara resolusi $10 \mathrm{~cm}$ memerlukan ketelitian horizontal minimum $5 \mathrm{~cm}$. Berdasarkan modul validasi rencana tata ruang Badan Informasi Geospasial, citra satelit resolusi tinggi membutuhkan ketelitian horizontal $\leq 20 \mathrm{~cm}$ (BIG 2016). Sedangkan LiDAR membutuhkan ketelitian horizontal $\leq 30 \mathrm{~cm}$ (Shamsi 2005). Untuk memenuhi ketentuan tersebut, telah ditetapkan ketentuan dasar terkait lama pengamatan dan metode yang digunakan. Pengukuran GCP CSRT dan LiDAR mengacu pada SNI 19-6724-2002 tentang Jaring Kontrol Horizontal dimana perlu dilakukan pengamatan selama 2 jam dengan menggunakan metode jaring (Nasional 2002). Berdasarkan penelitian terdahulu pengamatan GCP foto udara memerlukan waktu 20 menit dengan metode radial (Pribadi 2016). Sedangkan pada KAK BIG yang diterbitkan pada tahun 2017 tentang pengukuran GCP citra satelit resolusi tinggi dibutuhkan lama pengamatan minimum 45 menit untuk jarak baseline $0-30 \mathrm{~km}$. Pada saat pelaksanaan pengukuran sering kali terkendala masalah waktu dikarenakan kondisi tertentu yang tak terduga. Kondisi seperti ini dapat mengakibatkan ketidak sesuaian antara perencanaan dan pelaksanaan di lapangan. Maka dari itu, perlu dilakukan penelitian mengenai waktu minimum yang diperlukan untuk pengukuran GCP menggunakan GNSS berdasarkan metode dan lama pengamatan. Kemudian hasil penelitian ini diharapkan dapat menjadi alternatif dalam rangka pengukuran GCP dengan waktu yang efisien akan tetapi tetap mendapatkan hasil yang teliti.

\section{METODOLOGI PENELITIAN}

\section{Lokasi Penelitian}

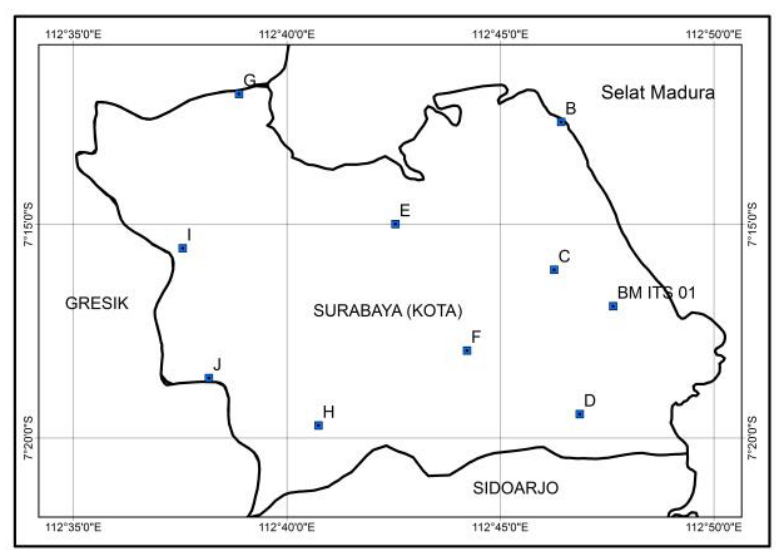

Gambar 1. Persebaran Titik GCP

Pengukuran GCP dilakukan di Surabaya dengan 10 titik. Pengamatan terikat pada BM ITS 01 dengan koordinat UTM 698075,011 m; 9194686,033 m pada Zona 49S. Masing-masing GCP diamati selama 
2 jam dan diproses dengan interval 15 menit (15', $\left.30^{\prime}, 45^{\prime}, 60^{\prime}, 75^{\prime}, 90^{\prime}, 105^{\prime}, 120^{\prime}\right)$. Hasil yang dianggap benar dan menjadi acuan adalah hasil pengolahan metode jaring dengan pengamatan minimum 2 jam.

\section{Data}

Data yang digunakan pada penelitian ini yaitu pengukuran langsung lapangan pada tanggal 24 Februari - 5 Maret 2018. Terdapat 10 titik GCP yang diukur menggunakan metode radial dan jaring dimana masing-masing pengamatan dilakukan selama 2 jam. Jarak baseline terpendek 2,98 $\mathrm{km}$ dan baseline terpanjang $18,7 \mathrm{~km}$.

\section{Peralatan}

Peralatan yang digunakan meliputi perangkat keras (hardware) dan perangkat lunak (software). Perangkat keras yang digunakan berupa receiver GPS Geodetik Topcon HiperPro, Sokkia GRX1 dan $\mathrm{Hi}$ Target v30. Sedangkan perangkat lunak yang digunakan adalah perangkat lunak komersil yakni Topcon Tools v8.2.3.

\section{Pra Survei}

Tahap pra survei merupakan tahap pembuatan perencanaan lokasi titik kontrol dan desain jaring serta alur pelaksanaan pengukuran. Berikut merupakan desain perencanaan pengukuran metode radial dan jaring.

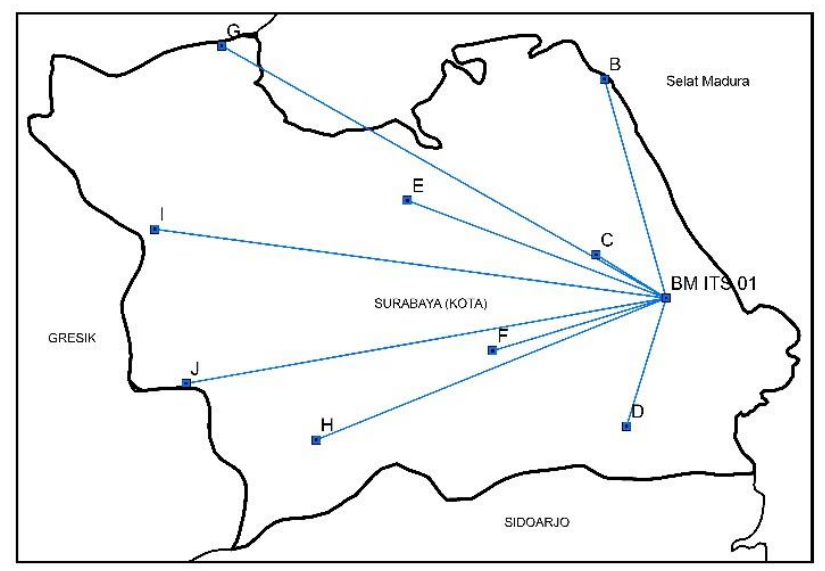

Gambar 2. Desain Radial



Gambar 3. Desain Jaring

\section{Pengukuran Lapangan}

Pengukuran lapangan dilakukan dengan metode radial dan jaring sesuai dengan desain dan alur yang telah dibuat sebelumnya. Lama pengamatan minimum adalah 2 jam. Titik acuan yang digunakan adalah BM ITS 01.

\section{Pengolahan Data}

Tahap pengolahan data dari penelitian ini dijelaskan pada urairan berikut:

1. Konfigurasi parameter

Tahap awal pembuatan project pengolahan adalah dengan mengatur konfigurasi dan beberapa parameter antara lain penyesuaian waktu, datum dan proyeksi yang digunakan serta ketelitian minimum yang dibutuhkan.

2. Pengolahan metode radial

Pada tahap ini mulai input data pengamatan selama 2 jam untuk semua titik dan parameter yang dibutuhkan antara lain tinggi antena dan koordinat titik referensi. Selanjutnya dilakukan pemotongan sinyal satelit yang terekam dengan kelipatan 15 menit. Sehingga untuk satu titik GCP dengan metode radial memiliki 8 hasil pengolahan (15 menit, 30 menit, 45 menit, 60 menit, 75 menit, 90 menit, 105 menit dan 120 menit). Berikut merupakan contoh pemotongan sinyal sesuai dengan waktu yang dibutuhkan. 


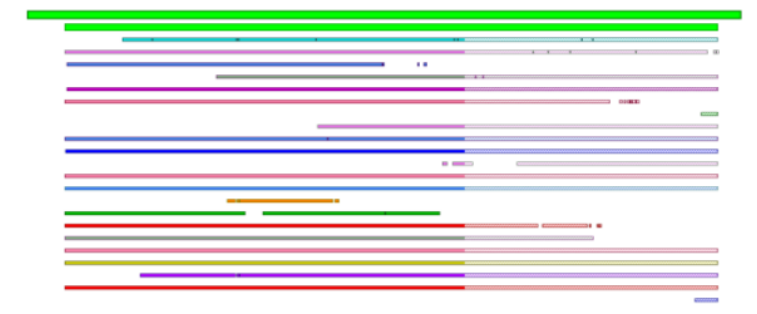

Gambar 4. Pemotongan Sinyal Satelit Berdasarkan Waktu

Setelah melakukan pemotongan sinyal satelit berdasarkan waktu, masuk pada tahap post processing yang selanjutnya didapatkan nilai koordinat dan RMS error. Dari hasil tersebut dapat dilihat apakah ketelitian yang didapatkan sudah memenuhi kebutuhan atau tidak. Apabila ketelitian tidak memenuhi toleransi maka dilakukan tahap pengecekan kontinyuitas sinyal. Apabila kontinyuitas sinyal cenderung kurang bagus, maka dilakukan pengeliminasian sinyal yang selanjutnya dilakukan kembali post processing.

3. Pengolahan Metode Jaring

Pada tahap ini mulai input data pengamatan selama 2 jam untuk semua titik dan parameter yang dibutuhkan antara lain tinggi antena dan koordinat titik referensi. Selanjutnya dilakukan post processing dan dilanjutkan dengan proses adjustment. Dari proses ini akan didapatkan nilai residu dan apabila terdapat baseline yang memiliki nilai residu lebih besar dari ketelitian minimum maka harus dilakukan pengecekan kontinyuitas sinyal.

\section{HASIL DAN PEMBAHASAN}

\section{Koordinat Referensi}

Pada penelitian ini menggunakan koordinat referensi berdasarkan hasil pengolahan data metode jaring dengan lama pengamatan 2 jam, mengacu pada SNI 19-6724-2002 Jaring Kontrol Horizontal. Berikut merupakan koordinat hasil pengolahan metode jaring:
Tabel 1. Hasil Pengolahan Koordinat Referensi

\begin{tabular}{ccccc}
\hline Titik & Easting $(\mathrm{m})$ & Northing $(\mathrm{m})$ & $\begin{array}{c}\text { Std Dev } \\
\text { Horz } \\
(\mathrm{m})\end{array}$ & $\begin{array}{c}\text { Jarak } \\
\text { dari base } \\
(\mathrm{km})\end{array}$ \\
\hline B & 696440,508 & 9202756,149 & 0,010 & 8,234 \\
C & 695537,968 & 9196271,665 & 0,007 & 2,992 \\
D & 696603,564 & 9190041,459 & 0,008 & 4,872 \\
E & 688687,041 & 9198268,936 & 0,009 & 10,048 \\
F & 691800,578 & 9192801,834 & 0,009 & 6,551 \\
G & 681967,107 & 9203906,701 & 0,011 & 18,560 \\
H & 685337,403 & 9189588,876 & 0,010 & 13,720 \\
I & 679559,319 & 9197261,146 & 0,011 & 18,694 \\
J & 680477,744 & 9191355,736 & 0,011 & 17,910 \\
\hline
\end{tabular}

Berdasarkan hasil pengolahan data metode jaring dengan lama pengamatan 2 jam dihasilkan nilai koordinat yang tertera pada Tabel 1 di atas. Nilai standar deviasi horizontal yang dihasilkan memiliki nilai minimum $0,007 \mathrm{~m}$ pada titik $\mathrm{C}$ dan nilai maksimum $0,011 \mathrm{~m}$ pada titik $\mathrm{G}$, I dan J. Jarak baseline terpendek adalah titik $C$ dengan 2,992 km sedangkan jarak baseline terpanjang adalah titik I dengan 18,694 km. Secara umum semakin panjang baseline titik pengamatan dengan titik control berpengaruh terhadap ketelitian koordinat titik pengamatan yang semakin menurun ${ }^{[9]}$.

\section{Hasil Pengolahan Radial}

Berikut ini merupakan grafik hasil pengamatan untuk setiap titiknya dengan lama pengamatan 15 -120 menit.

- Hasil Pengolahan Titik B

Titik B dengan panjang baseline $8,234 \mathrm{~km}$ memiliki rentang nilai standar deviasi horizontal $0,005 \mathrm{~m}$ hingga $0,009 \mathrm{~m}$. Nilai 0,009 terletak pada 15 menit pertama dan selanjutnya pada pengamatan 30 menit hingga 120 menit terjadi perubahan nilai standar deviasi horizontal dengan rentang $2 \mathrm{~mm}$. Berdasarkan Gambar 5 berikut diketahui bahwa perubahan nilai easting maupun northing dari pengamatan 15 menit hingga 120 menit tidak memiliki pola yang pasti. Nilai ketelitian easting yang paling baik adalah $0,001 \mathrm{~m}$ dan nilai tertinggi 0,022 . Nilai ketelitian northing paling baik adalah $0,005 \mathrm{~m}$ dan nilai tertinggi sebesar 0,012 m. 


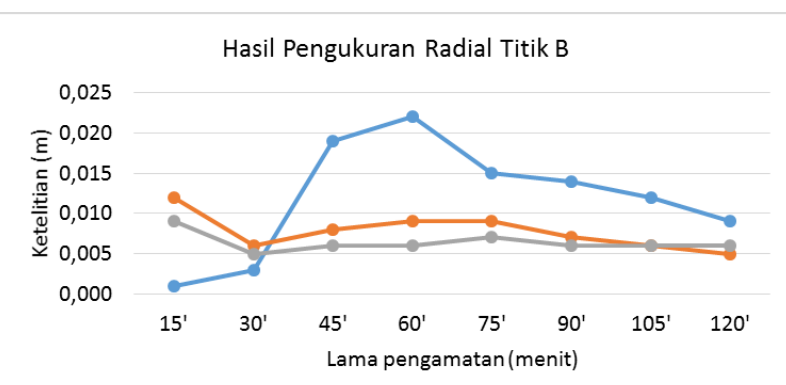

$\multimap$ Selisih Easting terhadap acuan $\multimap$ Selisih Northing terhadap acuan $\longrightarrow$ Std Deviasi Horizontal

Gambar 5. Hasil Pengolahan Radial Titik B

\section{- Hasil Pengolahan Titik C}

Pengamatan titik $\mathrm{C}$ menghasilkan nilai standar deviasi horizontal terkecil dengan nilai 0,002 $\mathrm{m}$ dan terbesar dengan nilai $0,003 \mathrm{~m}$, sehingga dari pengamatan 15 menit hingga 120 menit nilai standar deviasi horizontal cenderung stabil dan tidak terjadi perubahan signifikan. Sedangkan nilai easting dan northing cenderung memiliki pola yang sama. Nilai easting yang paling mendekati titik acuan berada pada hasil pengamatan 105 menit yaitu $0,007 \mathrm{~m}$, sedangkan nilai terbesar pada pengamatan 90 menit dengan nilai $0,012 \mathrm{~m}$. Nilai northing yang paling mendekati titik acuan berada pada hasil pengamatan 105 menit yaitu $0,004 \mathrm{~m}$, sedangkan nilai terbesar pada pengamatan 15 menit dengan nilai 0,009 $\mathrm{m}$.

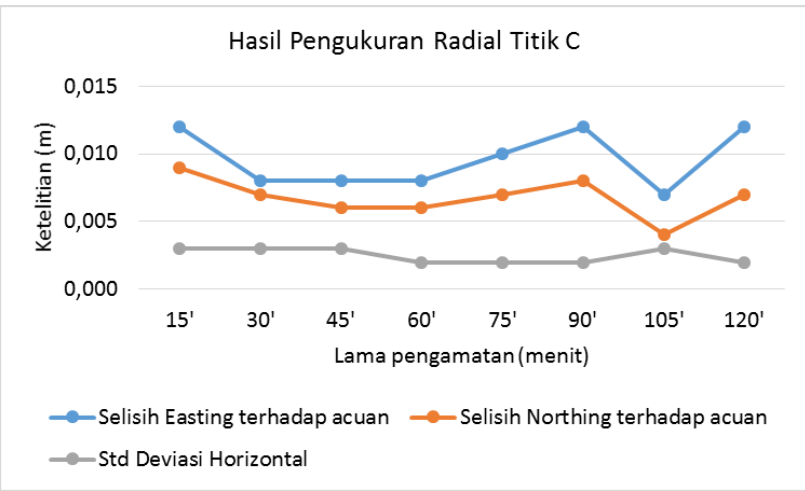

Gambar 6. Hasil Pengolahan Radial Titik C

- Hasil Pengolahan Titik D

Gambar 7 berikut menunjukan bahwa terjadi peningkatan nilai RMS error dari pengamatan 15 menit hingga 120 menit. Pada pengamatan 15 menit menghasilkan nilai standar deviasi horizontal $0,013 \mathrm{~m}$ dan pada pengamatan 120 menit menghasilkan nilai standar deviasi horizontal 0,004 m. Sedangkan pola yang dibentuk dari nilai easting dan northing tidak menunjukan pola peningkatan yang teratur. Nilai selisih easting terhadap acuan berada pada rentang 0,003 $\mathrm{m}$ hingga $0,014 \mathrm{~m}$ dan nilai selisih northing terhadap acuan berada pada rentang $0,003 \mathrm{~m}$ hingga $0,007 \mathrm{~m}$.

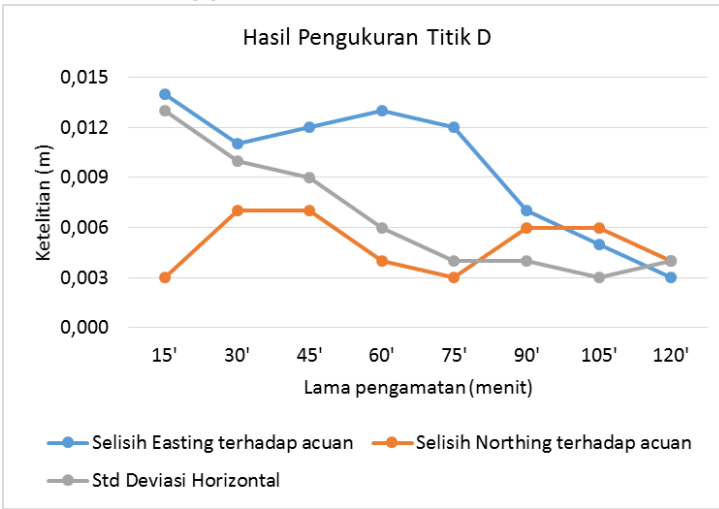

Gambar 7. Hasil Pengolahan Radial Titik D

- Hasil Pengolahan Titik E

Titik E dengan panjang baseline 10,048 km memiliki rentang nilai standar deviasi horizontal $0,010 \mathrm{~m}$ hingga $0,046 \mathrm{~m}$. Nilai 0,010 terletak pada 90 menit pertama dan nilai standar deviasi horizontal 0,046 dihasilkan oleh pengamatan 15 menit pertama. Berdasarkan Gambar 8 diketahui bahwa terjadi peningkatan ketelitian dari segi nilai standar deviasi yang dihasilkan akan tetapi perubahan nilai easting maupun northing dari pengamatan 15 menit hingga 120 menit tidak memiliki pola yang teratur. Nilai ketelitian easting yang paling baik adalah 0,002 $m$ dan nilai tertinggi 0,020 . Nilai ketelitian northing paling baik adalah $0,004 \mathrm{~m}$ dan nilai tertinggi sebesar $0,022 \mathrm{~m}$.



Gambar 8. Hasil Pengolahan Radial Titik E

- Hasil Pengolahan Titik F

Pengamatan titik $\mathrm{F}$ menghasilkan nilai standar deviasi horizontal terkecil dengan nilai 0,006 m 
dan terbesar dengan nilai 0,019 m. Nilai easting yang paling mendekati titik acuan berada pada hasil pengamatan 45 menit yaitu $0,007 \mathrm{~m}$, sedangkan nilai terbesar pada pengamatan 30 menit dengan nilai $0,025 \mathrm{~m}$. Nilai northing yang paling mendekati titik acuan berada pada hasil pengamatan 30 menit yaitu $0,024 \mathrm{~m}$, sedangkan nilai terbesar pada pengamatan 90 menit dengan nilai $0,039 \mathrm{~m}$.

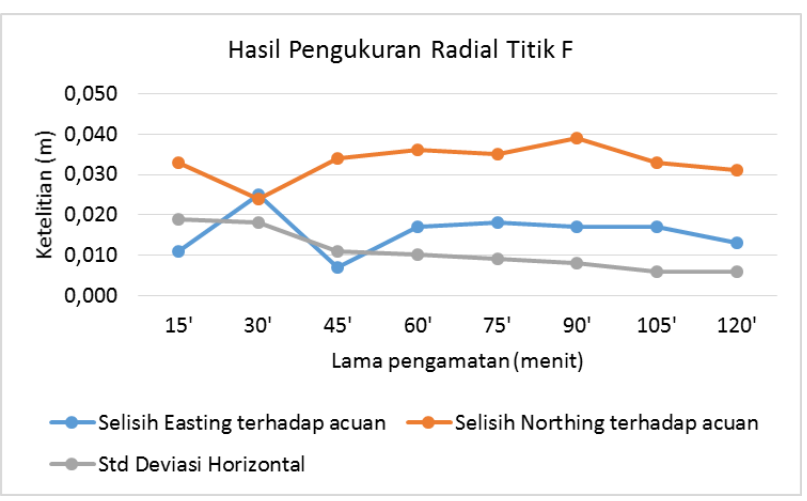

Gambar 9. Hasil Pengolahan Radial Titik F

\section{- Hasil Pengolahan Titik G}

Gambar 10 menunjukan bahwa terjadi peningkatan nilai standar deviasi horizontal dari pengamatan 15 menit hingga 45 menit, selanjutnya terjadi peruahan yang tidak signifikan. Nilai standar deviasi horizontal terendah adalah $0,007 \mathrm{~m}$ dan tertinggi adalah $0,019 \mathrm{~m}$. Nilai selisih easting terhadap acuan berada pada rentang $0,023 \mathrm{~m}$ hingga $0,028 \mathrm{~m}$ dan nilai selisih northing terhadap acuan berada pada rentang $0,014 \mathrm{~m}$ hingga $0,025 \mathrm{~m}$. Dari segi koordinat yang dihasilkan, terjadi penurunan ketelitian dimulai dari pengamatan 45 menit hingga 120 menit dengan rentang 4 $\mathrm{mm}$. Hal ini dapat disebabkan oleh jarak baseline yang jauh $(18,560 \mathrm{~km})$ dan data pengamatan base mengalami cycle slip.

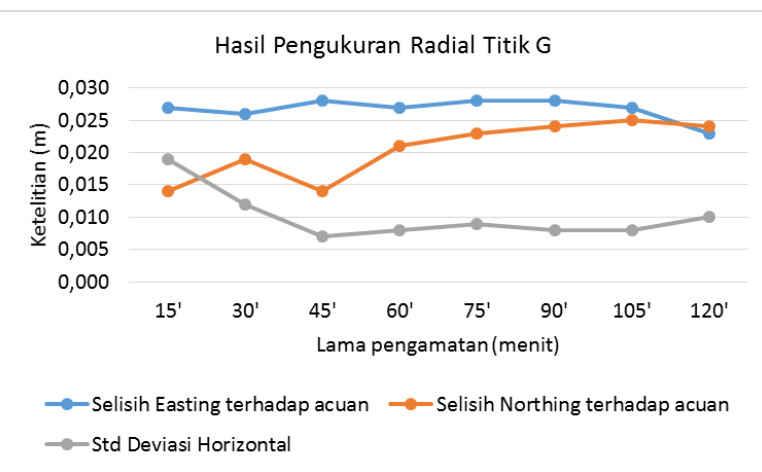

Gambar 10. Hasil Pengolahan Radial Titik G
- Hasil Pengolahan Titik $\mathrm{H}$

Titik $H$ dengan panjang baseline $13,720 \mathrm{~km}$ memiliki rentang nilai standar deviasi horizontal 0,08 $\mathrm{m}$ hingga 1,017 $\mathrm{m}$. Nilai standar deviasi horizontal pada pengamatan 15 memiliki nilai 0,924 $\mathrm{m}$ dan pengamatan 30 menit memiliki nilai $1,017 \mathrm{~m}$. Selanjutnya pada pengamatan 45 hingga 120 menit memiliki nilai standar deviasi horizontal pada rentang nilai 0,008 $\mathrm{m}$ hingga $0,013 \mathrm{~m}$. Perbedaan nilai yang cukup jauh tersebut dapat terjadi karena faktor jarak dan sinyal yang diterima. Sinyal yang didapatkan pada pengamatan 15 dan 30 menit hanya 17 sedangkan pada pengamatan 45 hingga 120 menit terdapat 21 sinyal satelit yang dapat diterima. Titik $\mathrm{H}$ membutuhkan waktu 45 menit untuk dapat digunakan sebagai GCP CSRT dan LiDAR dan membutuhkan waktu 75 menit untuk mencapai ketelitian dibawah $5 \mathrm{~cm}$ sebagai ketelitiaan minimum GCP foto udara resolusi 10 $\mathrm{cm}$.



Gambar 11. Hasil Pengolahan Radial Titik H

- Hasil Pengolahan Titik I

Pengukuran titik I menghasilkan nilai standar deviasi horizontal yang cenderung stabil dari pengamatan 15 hingga 120 menit dengan rentang nilai $0,007 \mathrm{~m}$ hingga $0,012 \mathrm{~m}$. Nilai easting yang dihasilkan cenderung mengalami peningkatan dalam rentang nilai $0,003 \mathrm{~m} \mathrm{-}$ $0,030 \mathrm{~m}$. Sedangkan nilai northing yang dihasilkan mengalami perubahan pada rentang $0,019 m-0,029 m$. 


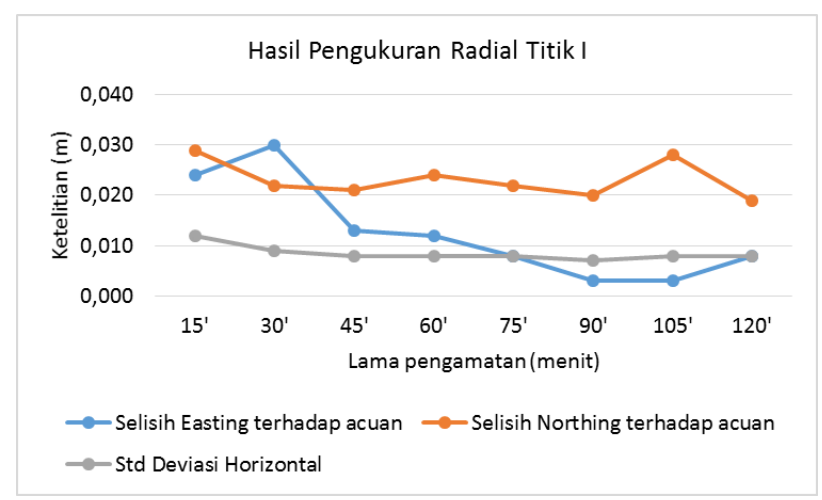

Gambar 12. Hasil Pengolahan Radial Titik I

\section{- Hasil Pengolahan Titik J}

Titik J dengan panjang baseline 17,910 km memiliki rentang nilai standar deviasi horizontal 0,011 $\mathrm{m}$ hingga 0,113 m. Berdasarkan Gambar 4.19 nilai standar deviasi horizontal mengalami peningkatan dari 15 menit hingga 120 menit. Nilai selisih easting terhadap acuan terkecil berada pada pengamatan $0,036 \mathrm{~m}$ dan terbesar pada pengamatan 15 menit yang mencapai 0,288 $\mathrm{m}$. Nilai selisih northing terhadap acuan terkecil adalah $0,002 \mathrm{~m}$ pada pengamatan 105 menit dan terbesar adalah $0,550 \mathrm{~m}$ pada pengamatan 30 menit. Pengukuran titik J membutuhkan waktu 60 menit untuk GCP LiDAR, dan 75 menit untuk dapat memenuhi ketelitian GCP foto udara resolusi $10 \mathrm{~cm}$ dan CSRT.

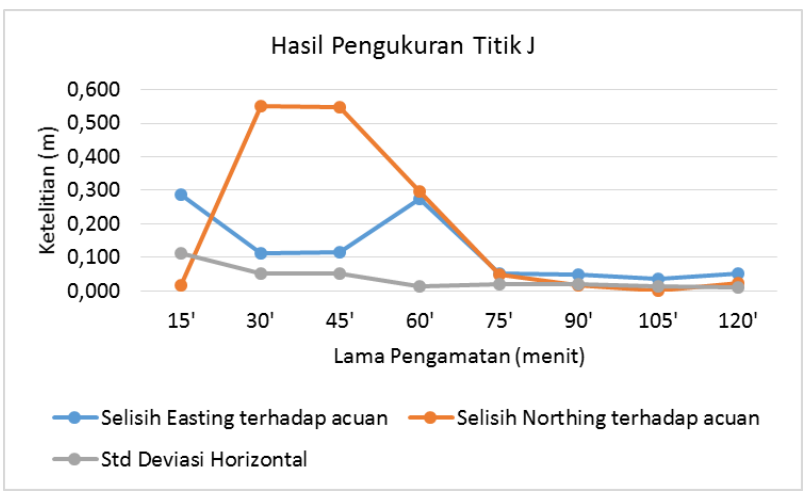

Gambar 13. Hasil Pengolahan Radial Titik J

\section{Analisa Berdasarkan Alat dan Panjang Baseline}

Berdasarkan seluruh hasil pengukuran radial di atas, apabila diklasifikasikan berdasarkan receiver yang digunakan maka hasilnya adalah sebagai berikut:
Tabel 2. Nilai Standar Deviasi Horizonal Berdasarkan Jenis Receiver dan Panjang Baseline

\begin{tabular}{ccrc}
\hline Alat & Titik & \multicolumn{1}{c}{$\begin{array}{c}\text { Panjang } \\
\text { baseline }(\mathrm{km})\end{array}$} & $\begin{array}{c}\text { Std Deviasi } \\
\text { Horizontal } \\
\text { Tertinggi }(\mathrm{m})\end{array}$ \\
\hline Hi-Target & $\mathrm{C}$ & 3,000 & 0,003 \\
V30 & $\mathrm{B}$ & 8,234 & 0,009 \\
& $\mathrm{I}$ & 18,694 & 0,012 \\
\hline Topcon & $\mathrm{F}$ & 6,551 & 0,019 \\
HiperPro & $\mathrm{G}$ & 18,560 & 0,019 \\
\hline & $\mathrm{D}$ & 4,872 & 0,013 \\
Sokkia & $\mathrm{E}$ & 10,048 & 0,046 \\
GRX1 & $\mathrm{H}$ & 13,720 & 1,017 \\
& $\mathrm{~J}$ & 17,910 & 0,113 \\
\hline
\end{tabular}

Berdasarkan Tabel 2 di atas dapat diketahui bahwa alat Hi-Target V30 memiliki tingkat presisi yang lebih baik daripada Topcon HiperPro dan Sokkia GRX1. Hi-Target V30 menghasilkan nilai standar deviasi horizontal tertinggi dengan nilai 0,012 m pada baseline 18,694 $\mathrm{km}$, Topcon HiperPro menghasilkan nilai standar deviasi tertinggi $0,019 \mathrm{~m}$ dan Sokkia GRX1 menghasilkan standar devisi tertinggi mencapai $1,017 \mathrm{~m}$.

Apabila dilihat berdasarkan panjang baseline, pada alat $\mathrm{Hi}$-Target V30 menunjukan bahwa semakin panjang baseline maka standar deviasi horizontal yang dihasilkan juga semakin besar. Receiver Topcon HiperPro menunjukan nilai standar deviasi horizontal maksimum yang sama antara titik yang memiliki baseline $6,551 \mathrm{~km}$ dengan $18,560 \mathrm{~km}$. Sedangkan untuk alat Sokkia GRX1 cenderung mengalami penurunan tingkat presisi dari baseline terpendek hingga terpanjang.

\section{KESIMPULAN}

Secara umum hasil penelitian menunjukan bahwa semakin lama pengamatan GNSS akan menghasilkan koordinat yang lebih akurat, dari ketelitian $0,923 \mathrm{~m}$ pada pengamatan 15 menit hingga $0,011 \mathrm{~m}$ pada pengamatan 120 menit. GCP dengan baseline 0-10 km menggunakan metode radial selama 15 menit dapat memperoleh akurasi kurang dari $5 \mathrm{~cm}$. Hal ini menunjukan bahwa hasil pengamatan tersebut dapat digunakan untuk rektifikasi foto udara resolusi $10 \mathrm{~cm}$, CSRT dan LiDAR. Panjang baseline 10-20 km membutuhkan 
waktu 90 menit untuk memperoleh ketelitian kurang dari $5 \mathrm{~cm}$ dan dapat digunakan untuk GCP foto udara resolusi $10 \mathrm{~cm}$, sedangkan CSRT dan LiDAR membutuhkan waktu pengamatan GCP 75 menit.

\section{UCAPAN TERIMA KASIH}

Penulis R. R. mengucapkan terima kasih kepada PT. Geosolution Pratama Nusantara yang telah mendukung penelitian ini dalam bentuk peralatan survei.

\section{DAFTAR PUSTAKA}

Abidin, H. Z. (2000). Penentuan Posisi GPS dan Aplikasinya. Jakarta: PT. Pradnya Paramita.

Bakara, J. (2011). Perkembangan Sistem Satelit Navigasi Global dan Aplikasinya. Berita Dirgantara, 12, 38-47.

BIG. (2016). Modul I-VI Sumber Data dan Peta Dasar. In Modul Validasi Peta Rencana Tata Ruang. BIG.

Nasional, B. S. (2002). SNI 19-6724-2002 Jaring Kontrol Horizontal. BIG.
Prasetyaningsih, D. (2012). Partisipasi Indonesia dalam Pembahasan Sistem Satelit Navigasi Global (Global Navigation Satellite System) . Berita Dirgantara, 13, 123.

Pribadi, K. K. (2016). Pengukuran dan Pengamatan Ground Control Point (GCP) dalam Misi Pemotreatan Udara di Area Pembangkit Listrik Tenaga Air Ketenger Kabupaten Banyumas. Bandung: Universitas Pendidikan Indonesia.

Pribadi, K. K. (2016). Pengukuran dan Pengamatan Ground Control Point (GCP) dalam Misi Pemotreatan Udara di Area Pembangkit Listrik Tenaga Air Ketenger Kabupaten Banyumas. Bandung: Universitas Pendidikan Indonesia.

Rahadi, M. E., Awaluddin, M., \& Sabri, L. (2012). Analisis Ketelitian Pengukuran Baseline Panjang GNSS Dengan Menggunakan Perangkat Lunak Gamit 10.4 dan Topcon Tools V7. Jurnal Geodesi Undip, 2, 208.

Shamsi, U. M. (2005). GIS Application for Water, Wastewater and Stormwater System. Florida. 